\title{
Diyarbakır Hevsel Bahçeleri ve Dicle Nehri: Arazi Değişimlerinin Jeomorfolojik Kayıtları
}

The Hevsel Gardens and The River Tigris in Diyarbakir: Geomorphological Archives of Landscapes Changes

\author{
Sabri KARADOĞAN ${ }^{1}$, Catherine KUZUCUOĞLU ${ }^{2}$ \\ 'Dicle Üniversitesi, Ziya Gökalp Ĕ̆itim Fakültesi, Coğrafya Ĕ̆itimi Anabilim Dalı, Diyarbakır \\ (skaradogan@dicle.edu.tr) \\ ${ }^{2}$ Université Paris 1 Panthéon-Sorbonne, \& CNRS (LGP, UMR 8591). 1 Place Aristide Briand, 92195 \\ Meudon cedex (France)
}

\section{ÖZ}

Çevre ve çevre sistemleri, geçmişten günümüze birçok medeniyetin ortak mirası özelliğindedir. Diyarbakır'da bulunan akarsu ve vadi sistemleri de bu özellikleri nedeniyle UNESCO Dünya Doğal ve Kültürel Miras listesine dâhil edilmiştir. Bu mirasın geleceği bir yandan insanoğlunun seçim ve eylemlerine bağlıyken, diğer yandan akarsu sisteminin gelişim seyrine ve dinamiklerinin etkisine bağlıdır. $\mathrm{Bu}$ tarihçe, akarsuyun taşkın ovası çevresinde gözlenen taraçalarda ve günümüzde derine kazıdığı ana kaya ile ilişkilerinde yazılıdır.

Dicle Nehri sisteminin evriminin anlaşılması amacıyla 2014 ve 2015 yıllarında gerçekleştirilen iki pilot bölgede arazi çalışmaları gerçekleştirilmiştir. Bunlar: (i) Akarsuyun, şehir duvarları (sağ yaka) ve Üniversite (sol yaka) çevresinde bulunan taraçaları üzerine kurulu Hevsel Bahçeleri, (ii) Diyarbakır Boğazı'nın aşağı çı̆̆ırlarında kalan, Karacadağ’ın să̆ yakasından Dicle’ye yakınsadığı kesimdeki alüvyal depolardır. İlksel sonuçlarımız, Dicle Nehri ve vadisinin evrimi hakkında önemli ipuçları ortaya koymaktadır. Uzun süreli dinamiklerin günümüz yer şekillerinin gelişimine ve akarsuyun geleceğine olan etkisi göz önünde bulundurulduğunda, Hevsel Bahçeleri ve Diyarbakır çevresindeki Dicle Vadisi’nin yönetimi ve korunmasının gerekliliği ortaya çıkmaktadır.

Anahtar Kelimeler: Dicle Nehri, Diyarbakır, Hevsel Bahçeleri, Holosen, Taraça. 


\section{ABSTRACT}

Environment and environmental systems have memories which become heritages common to several civilizations. The river and valley systems at Diyarbakır are such a heritage, which is now part of the UNESCO List of Natural and Cultural World Heritage. This heritage now depends today; first on our decisions and deeds, but also on the history of the system Dynamics which impacts the dynamics of the river whatever we do to it. This history is recorded in the terraces stretching along the river flood plain, and in the relationships between the river and the substratum that it incises.

In 2014 and 2015, we investigated two areas related to the recent evolution of the river: (i) the Hevsel gardens, which correspond to river terraces stepping at the foot of the city walls (right bank) and of the University (left bank); (ii) alluvial deposits downstream the Diyarbakır gorges, where right-bank from the Karacadağ converge towards the Tigris. Our first results provide new insights into the recent evolution of the Tigris valley and River. Enlightening the impact of long-term dynamics onto the present evolution of the landforms and onto the river's future, they directly address the management and preservation of the Hevsel Gardens and Tigris River valley in the Diyarbakir area.

Keywords: Diyarbakır, Hevsel Gardens, Holocene, Terraces, Tigris.

\section{GíRiş}

İnsanın yeryüzündeki faaliyetleri doğal çevreyle yakın ilişki içindedir ve bu faaliyetleri etkileyen doğal süreçlerin incelenmesi Kültürel Jeoloji kapsamında ele alınmaktadır (Kazanc1, 2005; Altunel, 2012).

Tarih ve tarih öncesi süreçte insan-çevre arasındaki karşılıklı etkileşimin unsurlarından biri de jeolojik-jeomorfolojik unsurlardır. Yukarı Mezopotamya eskiden beri çevre-insan etkileşiminin yoğun olarak yaşandığı ve bu etkileşim sonucu birçok uygarlığın ortaya çıktığ 1 bir coğrafyadır. Bu coğrafyada yakın çevresindeki doğal peyzaj unsurlarının avantajları ve etkileri ile kurulmuş, tarihi oldukça eskiye dayanan yerleşmelerden biri de Diyarbakır kentidir. Dicle Nehri, bölgenin diğer eski yerleşmeleri ve uygarlıkları gibi, bu nehrin kenarında kurulan Kadim Diyarbakır kenti için de önemli bir doğal peyzaj unsurudur (Karadoğan, 2015). Dolayısıyla nehir çevresindeki jeomorfolojik öğelerin, yeryüzünün şekillenme sürecine ait kayıtları ve izlerinin yanı sıra, özellikle her biri akarsu sekisi olan eski kent civarındaki bahçelerin, yani kültürel peyzaj alanlarının da insan faaliyetlerine ilişkin kayıtları içinde taşıması muhtemeldir. Bu amaçla Diyarbakır civarında Dicle Nehri vadisinde yer şekillerinin Kuvaterner dönemindeki evrimi ve kültürel yerbilimi açısından insan çevre etkileşiminin geçmişe ait izlerini ortaya koymak için bir çalışma programı gerçekleştirilmiştir. Diğer disiplinler tarafından yapılan çalışmalarla birlikte yürütülen ve sahanın kültürel yerbilim açısından önemini ortaya koymaya çalışan bu araştırma programlarının, araştırma sahasını içine alan Diyarbakır surları ve çevresinin "Diyarbakır Surları ve Hevsel Bahçeleri Kültürel Peyzajı" adıyla Unesco Dünya Miras Listesi'ne alınması sürecinde önemli katkıları olmuştur.

$\mathrm{Bu}$ makalede sözkonusu süreçte gerçekleştirilen çalışmaların kapsamı, amacı, yöntemi ve şu ana kadar elde edilen bulgular özetlenmektedir. 


\section{ÇALIŞMANIN KAPSAMI, AMACI VE METODU}

Araştırma alanı Diyarbakır civarında Dicle Nehri vadisi ve çevresini kapsamaktadır (Şekil 1). Çalışma alanı Dicle'nin kaynağını aldığı Güneydoğu Toros dağlarına yakın bir konumda yer alır. Dicle Nehri bu dağlar üzerinde Fırat Nehri havzasına oldukça yaklaşır. Her iki havzanın jeomorfolojik geçmişinde yaşanan drenaj ilişkileri ve değişikliklerinin aydınlatılması bölgesel jeomorfoloji açısından oldukça önemlidir.

Saha Prehistorya ve Antik dönemler için de oldukça önemlidir. Çünkü Diyarbakır kenti ve yakın çevresi toprak, iklim, su, savunma ve hammadde olanakları açısından Dicle Havzası'nda farklı bir konuma sahiptir. Yukarı Dicle HavzasıYukarı Mezopotamya, ya da "Bereketli Hilal" olarak adlandırılan bu alan Paleolitik'ten Tunç Çağlarına kadar özellikle obsidiyen ve bakır kaynakları açısından Prehistorya tarihinin önemli bölgeselölçekliyerleşmeleriarasındakibağlantıları sağlamış, sonraki dönemlerde ise SuriyeArabistan düzlükleri ile Anadolu-Kafkasya'daki maden bölgeleri ile yüksek irtifadaki ovalar ve meralar arasında bir geçiş güzergahı olagelmiştir. $\mathrm{Bu}$ nedenle bölgesel anlamda iklim, jeomorfoloji, çevre, insan ve toplumlar arasındaki ilişkilerin ve bağlantıların kurulması gerekir. Bu bağlamda aşağıdakiler amaçlanmıştır:

- Nehir ve günümüz çevre dinamikleri arasındaki bağlantıları kurarak, akarsu aşındırma faaliyetlerinin derecesini, Dicle Nehri ve kollarının yeryüzü şekillenmesindeki etkisinin anlaşılması ve sedimantasyon fazlarının belirlenmesi;

- Nehir-volkanizma-örtülü karst ilişkilerinin belirlenmesi (Doğan 2005a; Bridgland ve di ̌̆., 2007; Westaway ve diğ., 2009);

- Ön-Holosen ve post-Roma nehir dinamikleri hakkında ipuçları elde edilmesi (12000 yıl öncesinden başlayan kronoloji içinde, Holosen başından beri geçmiş insan toplulukları ile vadi arasındaki ilişkilerin ortaya konması) amaçlanmıştır (Kuzucuoğlu, 2002 ve 2003; Doğan, 2005b; Karadoğan ve Kozbe, 2013).

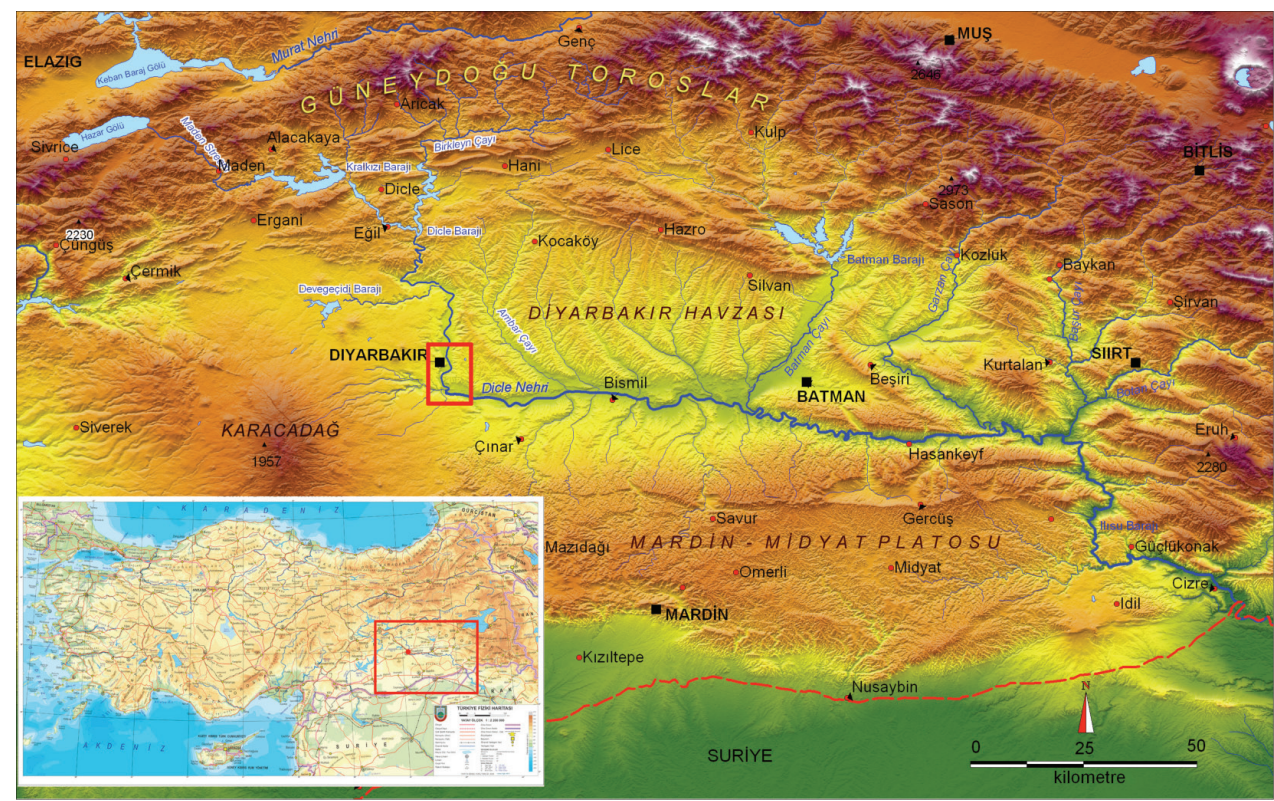

Şekil 1. Araştırma alanının lokasyon haritası.

Figure 1. Location map of the study area. 
Araştırma alanı daha sonra yapılacak Yukarı Dicle Havzası vadilerini ve yan kolları kapsayacak araştırmaların başlangıcı ve anahtarı rolündedir. Elde edilen sonuçlar, bilimsel amaçlar doğrultusunda kapsamları tanımlanan konular üzerinde, birbirine paralel ancak tamamlayıcı yaklaşımlar yoluyla belirlenecektir. Bunlar:

1) Jeomorfolojik yaklaşım: Dicle Vadisi, yan kollar ve çevresindeki plato alanları,

(a) Antik dönemin yeniden inşası için sedimanların ve yer şekillerinin oluşma ortamlarının evrimlerinin araştırılması,

(b) Her sedimantasyon/erozyon (birikim/ aşınım) döneminin mekansal dinamiklerinin (taşkın yatağı yapıları: akış rejimleri ve sediman yükü değişiklikleri, menderes oluşumu ve kopmalar, yarılma yerleri ve büyüklüğü vb.) haritalanmas1,

2) Sondaj çalışmaları,

3) Laboratuar analizleri: paleoortamlar hakkında bilgi verebilecek minerallerin (kil minerali, karbonatlar, volkanik küller) ve biyolojik materyallerin (özellikle diatom, polen) yaşlandırılması. Kronoloji, organik madde bakımından zengin tabakalara ait karakteristik dizilerin C14 yöntemiyle tarihlendirilmesi yoluyla yapılacaktır.

Arazi çalışmaları ve laboratuar analizleriyle ortaya çıkacak çevresel kayıtlara ilişkin olası bulgular:

(a) Bölgesel jeomorfolojik ve klimatolojik değişimleri,

(b) Bölgesel ve yerel tektonizma (fay aktivitesi ve depremler) etkileri,

(c) Eski arazi kullanımı, akarsu havzasındaki uygulamalar gibi verilere ulaşmamızı sağlayacaktır.
Böylece, elde edilecek sonuçlar, Güneydoğu Anadolu'nun diğer alanlarında (Adıyaman havzası, Orta Firat havzasi), Doğu Anadolu'da (Elazığ, Malatya Firat havzası) veya doğu-orta Anadolu'da (Van Gölü, Yukarı Fırat havzası) elde edilecek sonuçlarla karşılaştırma imkan1 verecektir.

Bütün bu karşılaştırmalarveyorumlamalar aynı zamanda Suriye'nin kuzeyinde Frrat Havzası'nda gerçekleştirilen diğer jeomorfolojik çalışmalara da yol gösterecektir.

Diyarbakır civarında Dicle Vadisi'nde gerçekleştirilecek bu çalışmanın beklenen sonuçları, hidrolojik/jeomorfolojik evrimin ve paleoçevresel sorunların aydınlatılması bağlamında Dicle Nehri'nin mansap havzası ile Firat Nehri hatta Van Gölü havzasına kadar uzatılması konusunda yeni çalışmalara ihtiyaç doğurabilir.

\section{Tespit edilen Problemler}

İlk arazi çalışmaları ve saha gözlemleri sonucu aşağıda sıralanan bazı problemler belirlenmiştir.

I - Havzanın Jeomorfolojik evrimine ilişkin problemler:

- Pliyosen'den bugüne drenaj geometrisi nasıl gelişmiştir?

- Bölgeye özgü ne gibi köklü jeomorfolojik değişiklikler olmuştur?

- Kapmaların Dicle Nehri üzerinde ne gibi etkileri olmuştur?

- Karacadağ volkanik etkinliği akarsu drenajını nasıl etkilemiştir? 
- Dicle ve Firat paleodrenajı bölünmüş müdür? (Varsayım: Muhtemelen Karacadă̆ volkanik kütlesi vadiyi kapatarak bölgede bir göl görünümü oluşturmuş, daha sonra bir dirsekle nehrin akış yönü doğuya dönmüştür).

II- Diyarbakır kenti çevresine ilişkin jeomorfolojik problemler:

- Diyarbakır kenti güneyindeki akarsu dirseğinin nedeni ne olabilir?

- Kent civarında ve nehir çevresinde görülen ilginç jeomorfolojik oluşumlar ve tezatlıkların (boğaz ve genişlemeler, vb) nedenleri nelerdir?

- Hevsel genişlemesi neden boğazın kuzeyinde oluşmuştur?

- Vadi asimetrisinin nedenleri nelerdir?

- Kırklar Dağ1 Tepesi (bazaltik mesa) ve boğazının kökeni nedir (Pliyosen sonrası epijenik kökenli mi?)

- Vadideki akış yönü değişikliklerinin, menderes dinamiğinin ve ana kayanın kesilmesinin nedenleri?.

- Terkedilmiş kanalların nedenleri ne olabilir?

III - Kültürel yerbilim açısından; eski arazi kullanımı, tarihsel önem-mitoloji:

- Geçmişte, nehrin çevre dinamiklerinde ve arazi kullanımında ne gibi değişiklikler olmuştur? Hangi çevresel ve beşeri faktörler bir birini etkilemiştir?

- Büyük iklim krizlerinin ve kuraklıkların yaşandığ1 dönemlerde bile münbit özelliğini koruyan bu alanın uygarlıklar ve insan çevre etkileşimi açısından önemi nedir?
- Bahçeler tarihsel kaynaklarda (Perez, 2015) neden "Eden Cenneti" olarak ifade edilmiştir?

- Türkülere ve efsanelere konu olmuş, üç büyük din inanışına göre kutsallık atfedilen bazaltik Kırklar Dağı (Tepesi) bu özelliğini nereden almıştır?

- Sulama kanallarının kullanımı ve terk edilmesinin nedenleri?

- Doğal ve kültür bitki örtüsündeki değişimin nedenleri?

\section{YÜRÜTÜLEN ÇALIŞMALAR VE BULGULAR}

$\mathrm{Bu}$ sorular ve problemler ekseninde Dicle Vadisi ve çevresinde gerçekleştirilen jeomorfolojik çalışmalar üç grupta toplanabilir:

A- Birimlerin tanınması (fasiyes, kalınlık gibi stratigrafik özellikler) ve belirlenmesi, taraça ve yüzeylerin yükseltilerinin ölçümüne yönelik saha ve kartografya çalışmaları. Bu kapsamda 2014 ilkbahar ve sonbaharında sistematik gözlem ve arazi çalışmaları gerçekleştirilmiştir. Terk edilmiş bir menderes dolgusu içinde karotlu sondaj yapılmıştır. Surlardan Dicle Nehri'ne kadar olan alanda GPS ölçümleri yapılarak yüzeylere ait eğim derecesi, eğim kırıklıkları ve yükseltileri belirlenmiştir. Uydu görüntüleri, eski harita ve fotoğraflardan da yararlanılarak, harita, kesit ve profiller oluşturulmuştur (Şekil 2, 3, 4).

B- Dicle nehri taraçalarının dinamik evriminin aydınlatılmasına yönelik çalışmalar (Dicle Vadisi ve taraçaların ayrıntılı Jeomorfoloji Haritas1, Jeomorfolojik kesitler, hava, uydu ve arazi verilerine göre, yakın zamanda nehir yatağ değişikliklerinin tespiti, Şekil 4, 5). 


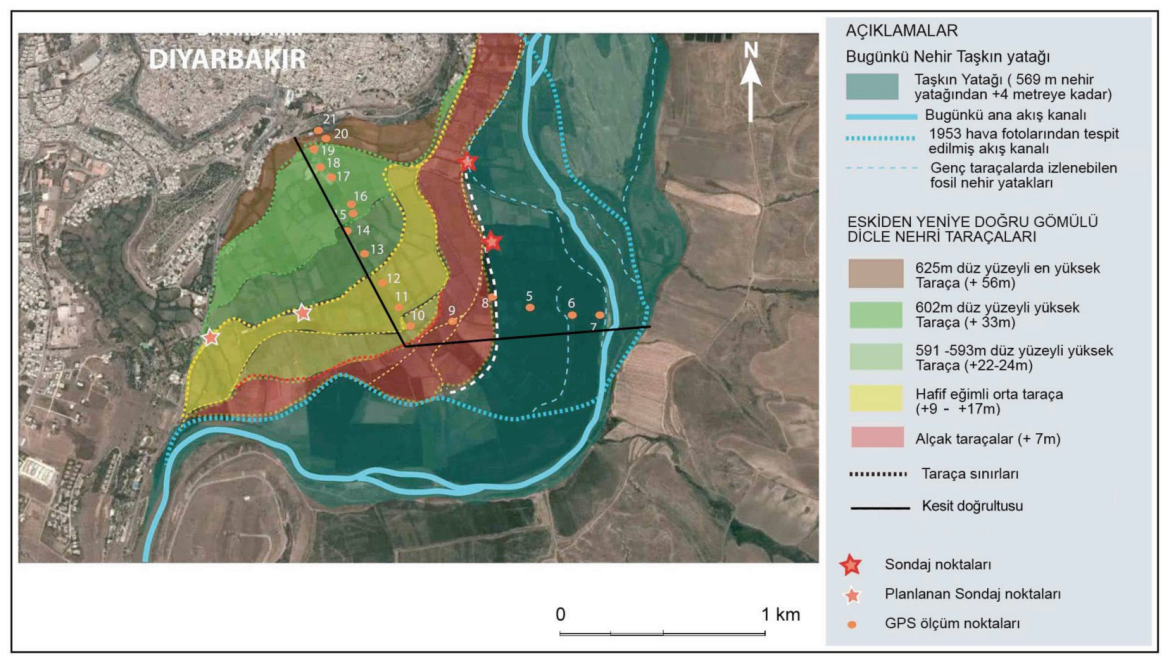

Şekil 2. Hevsel Bahçeleri'nin üzerinde bulunduğu Dicle Nehri taraçalarının jeomorfoloji haritası.

Figure 2. Geomorpholojical map of the River Tigris terraces in the Hevsel gardens.

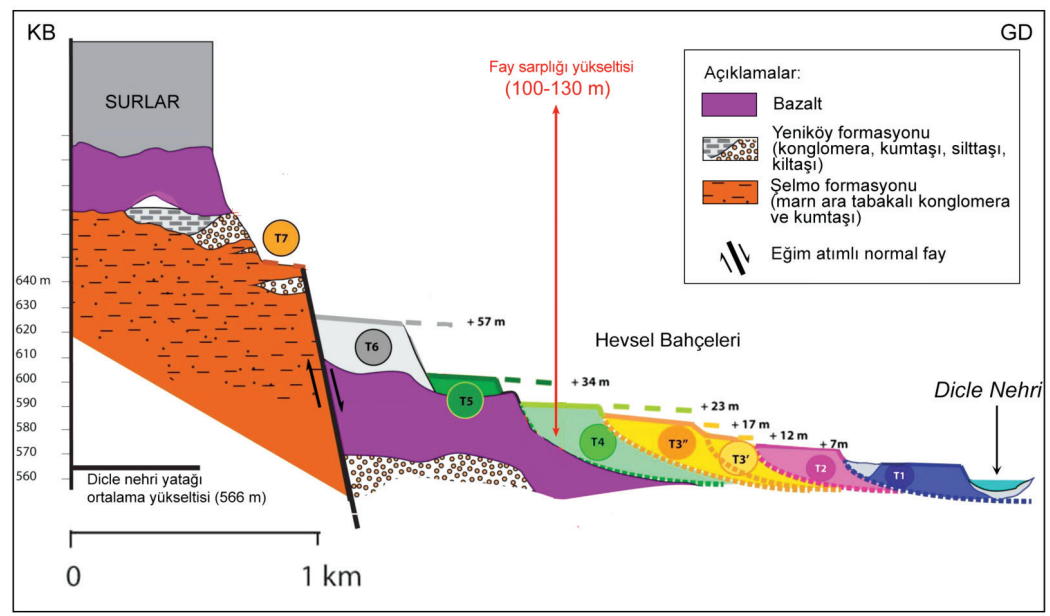

Şekil 3. Dicle nehri kanalı ile Diyarbakır Kent surları arasının Hevsel Bahçeleri boyunca jeolojik kesiti. Açılama: 1-Kahverengi: Ana kaya, kırmızı kilden oluşmaktadır. Yer yer bataklık (gri kil), göl ve akarsu depolarıyla kesilmektedir. 2-Mor renk: Karacadağ'dan gelen masif siyah bazalt akışı, kil ana kayasından oluşan fosil topoğrafyayı örtmektedir. 3-Dicle Nehri'nin her taraçası farklı renklerle çizilmiştir (En eski ve en yüksek taraça "T6", gri renkte, en genç ve en alçak taraça "T1" lacivert). T2 yamacı altındaki gri kanal, T1 akış sistemine aittir. Nehir kollarına ait terk edilmiş bir menderes kanalına karşı1ık gelir. 4-Fay sarplığı kısmen en eski taraça (T6) depolanmasından önce nehir aşındırılması ile açığa çıkarılmıştır. Dikey kırmızı çizgi, düşey atımlı fay hareketinin tahmini büyüklüğünü göstermektedir.

Figure 3. Geological cross-section from the River Tigris river channel to the Diyarbakur City wall through the Hevsel Gardens. Legend: 1-Brown colour: bedrock, constituted by red clay. It is eroded by gravelly fluvial beds interrupted by marshy/lake events (grey clay) 2-Purple colour: massive black basalt flow from the Karacadağ, fossilizing the eroded alluvial deposit blanketing the clay bedrock 3-Each terrace of the River Tigris is drawn with a distinct colour. The oldest is the highest ("T6", in grey). The youngest terrace is "T1", in dark blue. The "grey" channel at the foot of T2 scarp belongs to T1 flat. It records the abandonment of one of the river beds (a meander?) before the ultimate incision of today's river main channel into T1 terrace which belongs to today's flood plain. 4-The fault scarp (spotted line red) is partly revealed by the river erosion before the deposition of the oldest terrace T6. The double arrowed vertical red line shows the estimated magnitude of the fault upward movement. 


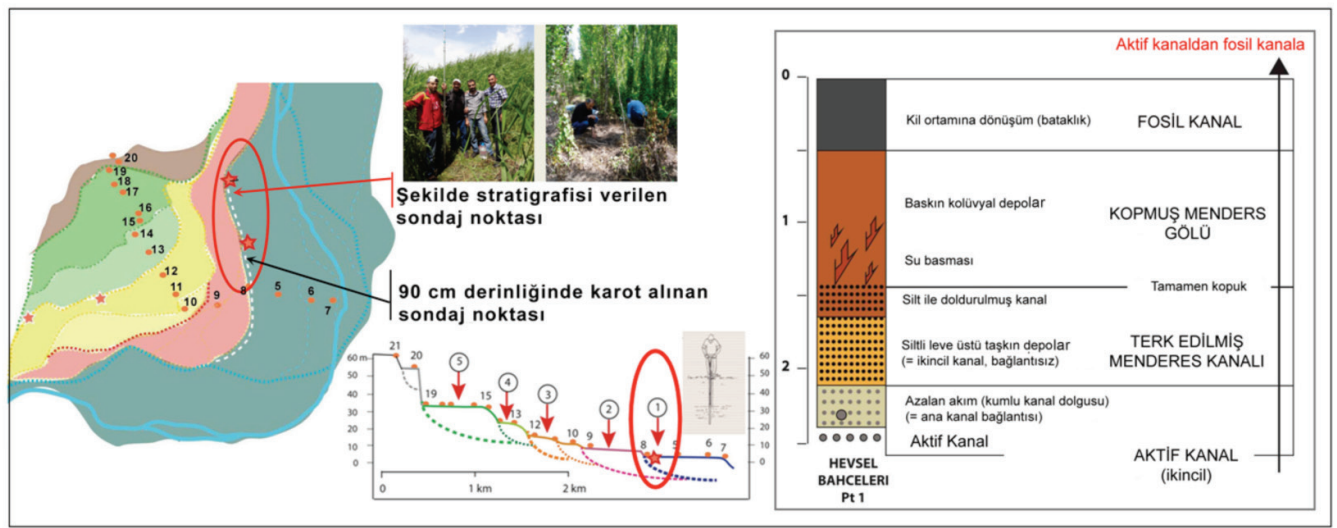

Şekil 4. Hevsel Bahçeleri taraçalarında el sondajı yapılan noktalar. Sağda, kuzeydeki 2.5 metrelik sondaj noktasının stratigrafik kesiti ( $37^{\circ} 54^{\prime} 11.69^{\prime} \mathrm{N}-40^{\circ} 14^{\prime} 44.69^{\prime}$ 'E).

Figure 4. Points of hand coring in the Hevsel Gardens terrace. Right, Stratigraphy of the $2.5 \mathrm{~m}$ long Core Spot sequence $\left(37^{\circ} 54^{\prime} 11.69^{\prime \prime} \mathrm{N}-40^{\circ} 14^{\prime} 44.69^{\prime \prime} \mathrm{E}\right)$.

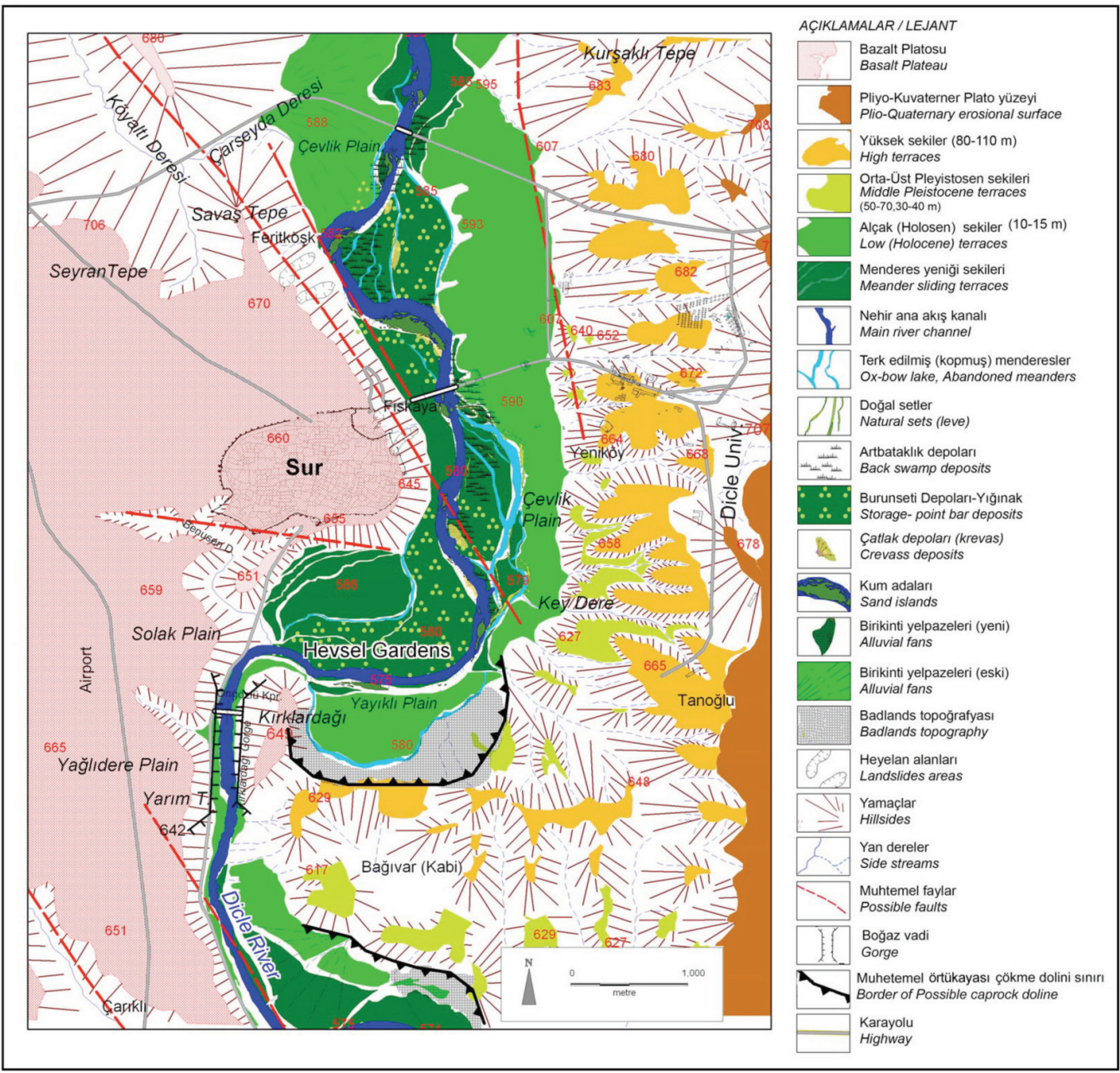

Şekil 5. Diyarbakır kenti doğu ve güneydoğusunda Dicle Nehri vadisi ve çevresinin jeomorfoloji Haritasi.

Figure 5. Geomorpholojical map of the Dicle River valley and its surroundings in eastern and southern Diyarbaktr city. 
Arazi çalışmaları esnasında kent tabanında çoğunlukla kalker litolojili, yer yer tabanında ve vadi yamaçlarında en az 3 fasiyesli bazalt akışının gerçekleştiği belirlenmiştir. Ayrıca, yamaçlarda, surların hemen altında bazaltların çakıltaşı, gri kil halinde, ama hemen hemen tümü yanmış klastikler olan kırıntılı bir tabaka dikkat çekmektedir (Şekil 6).
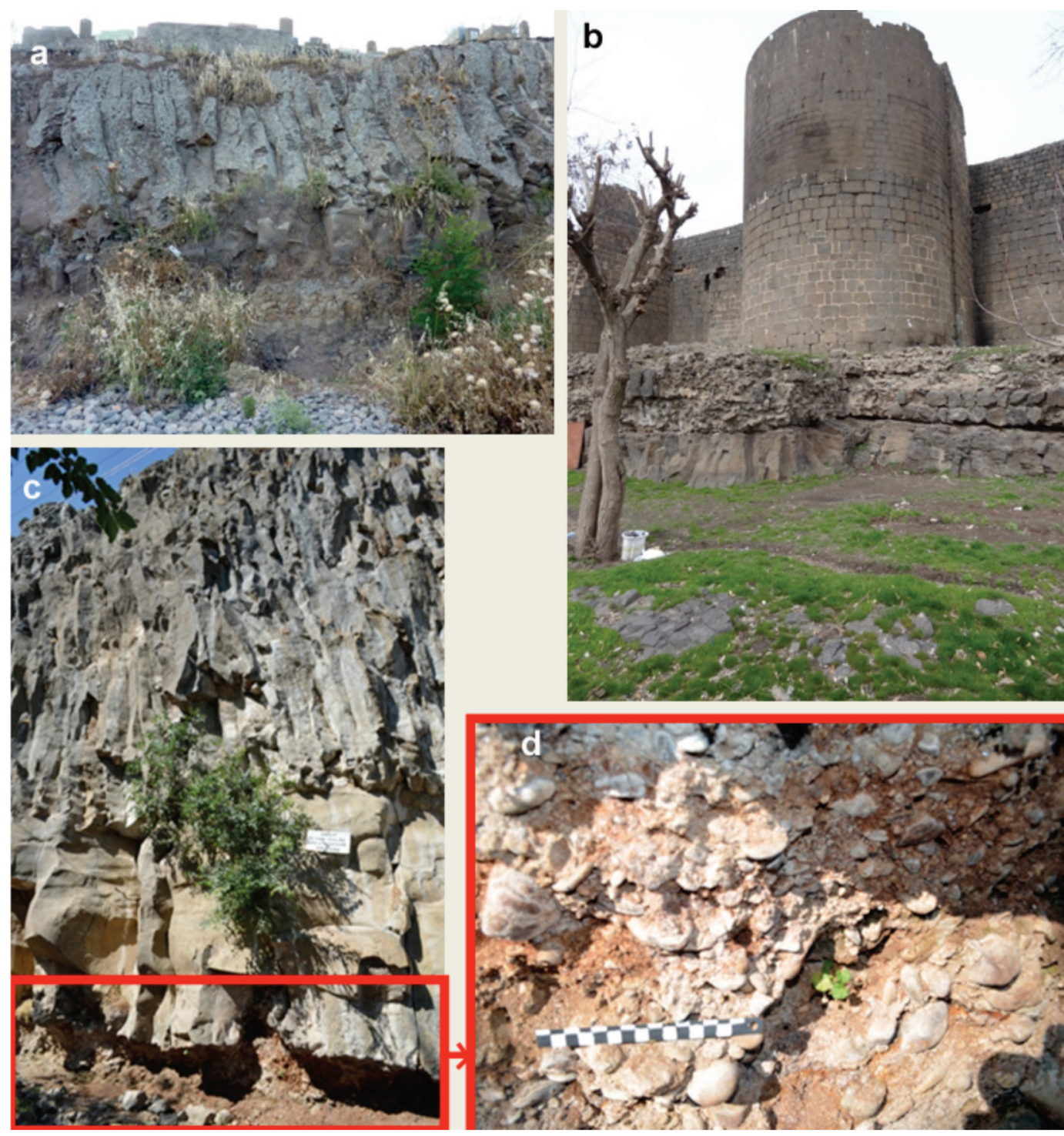

Şekil 6. Diyarbakır kentinin üzerine kurulduğu bazalt platosunda farklı dönemlere ait bazalt akıntıları ve bazalt örtü altında kalker ve kil litolojili yanmış klastikler.

Figure 6. Basalt flows belonging to different periods in the basalt plateau, which was built on the city of Diyarbaklr and burnt clastics with limestone and clay lithology under basalt cover. 
Yine arazi çalışmaları esnasında sur duvarları altında kayaçların, çoğunlukla, kaymış bir kolüvyal malzeme ile kaplanmış olduğu, genellikle çakıl, bazen çakıl lensler ile kesintiye uğrayan, karbonatlı paleosol tarafından değiştirilmiş pekleşmiş kırmızı kil oluşumu dikkati çeken diğer hususlar olmuştur (Şekil 7). Saha gözlemleri ve bulguları kent civarında en geniş taraçaları oluşturan Hevsel Bahçeleri'nin çok dönemli menderes yeniği taraçaları (menderes kaymas1 - göçü) olduğunu ortaya koymuştur. Arazi çalışmaları esnasında dikkati çeken gözlemlerden biri de T7 ile T6 taraçaları arasında taraça yamacı olarak kabul edilemeyecek bir dikliğin ve belirgin bir yamaç sarplığı ile T6 ve T5 taraçaları bünyesinde bulunan bazalt bloklarının varlığıdır.

Arazi ölçüm ve bulgularına dayanılarak surlar ile bahçeler arasındaki bu belirgin eğim kırıklığının bir fay sarplığı olduğu sonucuna varılmıştır. Ancak düşey atımlı bu faylanmanın bir sübsidans eseri olan düşme mi, yoksa bir tür tektonizma etkisine bağlı olarak mı oluştuğu hala önemli bir problemdir.
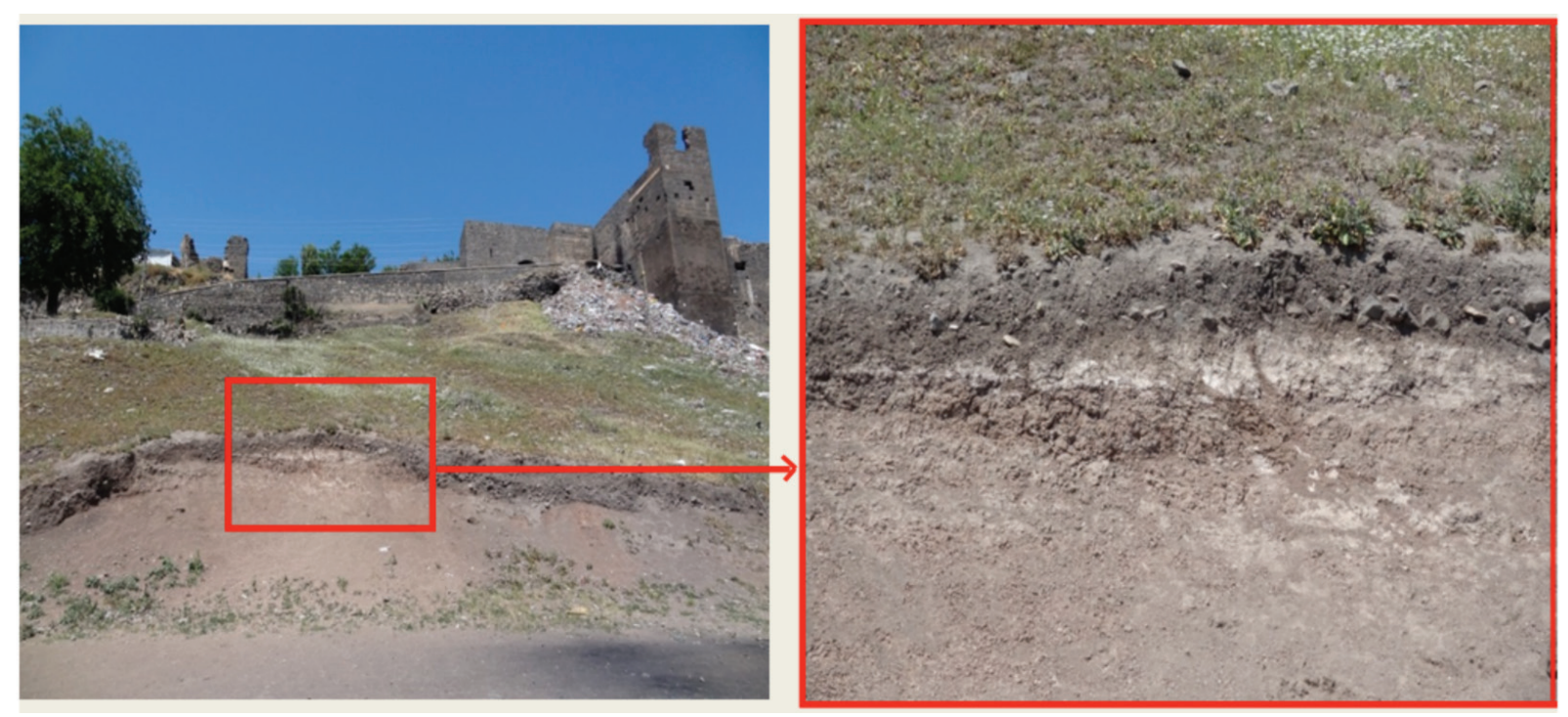

Şekil 7. Surlar ile bahçeler arasındaki (T7-T6 arası) Pliyosen dönemi çökelleri yamacında oluşmuş belirgin eğim kırıklığı. Yamaç altında kayaçlar, çoğunlukla, kaymış bir kolüvyal malzeme ile kaplanmış ve genellikle çakıl, bazen çakıl lensler ile kesintiye uğrayan, karbonatlı paleosol (volkanik kül değil ise toprak suyuyla harekete geçirilerek oluşmuş bir karbonat birikim zonu) dikkati çekiyor.

Figure 7. The oldest substratum rock in the Hevsel Gardens area The substratum rock is here a red clay, eroded from Pliocene era slopes and soils. It possibly accumulated in lakes. The lime-content has been mobilized by soil water to form a carbonate (white) accumulation on top of the deposit (unless it is a volcanic ash?). The uppermost black deposit is the present slope soil with reworked material. 


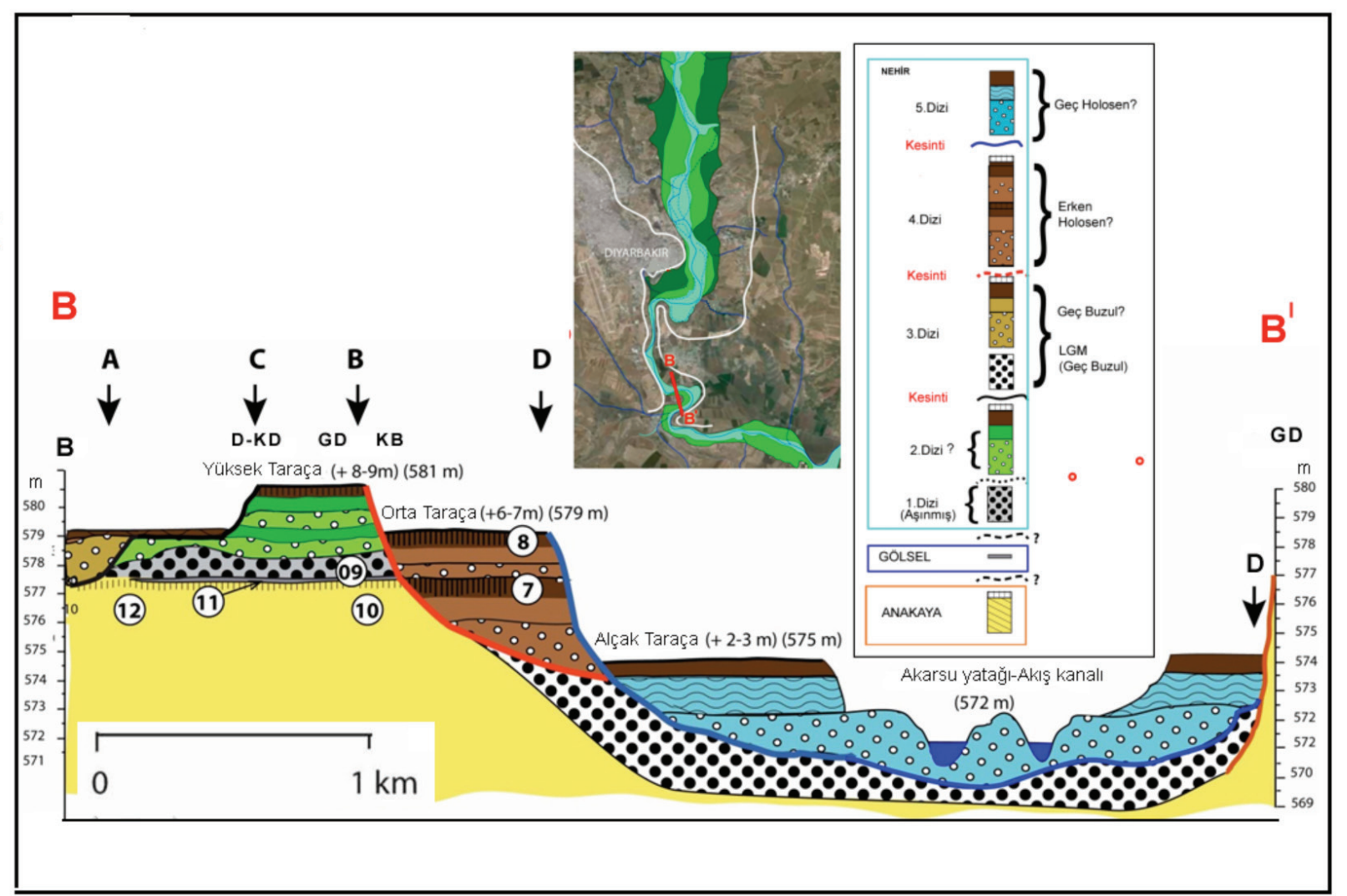

Şekil : 8. Dicle Nehri'nin doğuya doğru dirsek oluşturduğu Çarıklı civarına ait profil kesit.

Figure 8. Profile section of the vicinity of Çarlkll where the Dicle River forms an elbow towards the east.

C- Daha sonra taraçalarda erozyon dönemlerine ait sedimentleri tespit etmek ve fasiyesleri ayırt edici birimlerin yaşlarını belirleyebilmek amaciyla karotlu sondaj yapılmıştır.

2015 ilkbaharında Holosen boyunca alüvyal biriktirme, aşındırma faaliyetlerinin aşamalarının ve yaşlarının belirlenmesi amacıyla kentin kuzeyinde nehrin sol yakasında kamyona monte edilmiş sondaj aracıyla karot alınmıştır.
Vadinin en alçak seki dolguları içindeki çimentolaşmış sert bir katmanın varlığı ve 1 slak topraklar bazı yerlerde karot alınmasını engellese de iki ayrı yerden sondajla karot örneği alınmıştır. Bunun dişında kentin güneyinde nehrin boğazdan sonra dış bükey menderes yaptığ 1 alandaki alçak taraça dolguları detaylı çalışılarak birkaç alüvyal ardalanma tespit edilmiş ve radyokarbon tarihlendirmelerinin yapılması için laboratuara gönderilmiştir. 


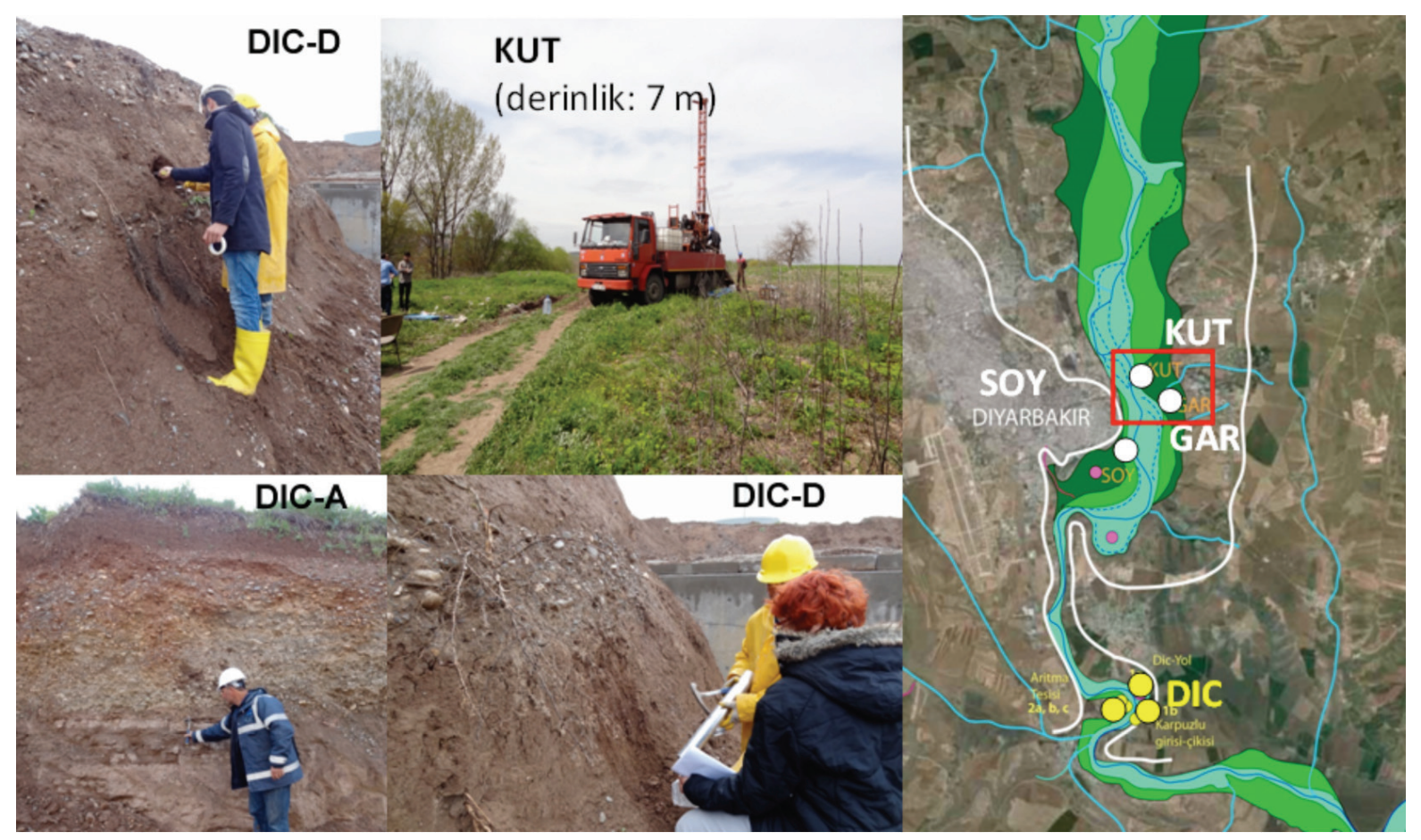

Şekil 9. Sondaj yapılan ve yaşlandırma örnekleri alınan noktalar.

Figure 9. Coring and Sampled points for laboratory aging.

\section{SONUÇLAR}

İnsanın yeryüzündeki yaşam alanlarını ve faaliyetlerini büyük ölçüde doğal koşullar ve süreçler belirler. Fakat insan toplulukları zaman zaman bu doğal işleyiş ve süreçleri etkilemiş ya da kullanmış, bir etkileşim içine girmiştir. Yerkabuğunun şekillenmesi ve kullanımı bağlamında bu karşılıklı etkileşim kültürel jeoloji ve kültürel jeomorfolojinin konusunu oluşturur.

Kültürel jeoloji ve kültürel jeomorfoloji açısından insanın çevresiyle sürekli etkileşim içinde bulunduğu kültürel peyzaj örneklerinden biri de Diyarbakır eski kenti ve yanı başındaki Dicle Nehri vadisidir.

Çevresel değişimlerin izlerinin jeomorfolojik kalıntılarda saklı olduğu olgusundan hareketle, Diyarbakır kenti ile doğal çevresi arasındaki ilişkilerin aydınlatılmasına yönelik bir dizi çalışma yürütülmüştür. $\mathrm{Bu}$ çalışmalar sonucunda Diyarbakır civarında Dicle nehir peyzaj özelliklerinin oluşumunda:

- İklim değişimleri ve buna bağlı olarak akarsu enerjisinde meydana gelen değişmeler,

- Litolojik faktörlere bağlı mekansal değişimler,

- Yerel ve bölgesel tektonik faktörler,

- Volkanizma olaylarının etkili olduğu, morfolojik evrimde gençleşmelerin, çok dönemli evrelerin olduğu sonucuna varılmıştır.

Dicle Vadisi'nin oluşumu ve evriminde oldukça dinamik çevresel işleyişler etkili olmuştur. Tarım, sulama, sayfiye ve peyzaj öneminden dolayı bu dinamizm içine insan da katılmış, çevresel yeryüzü öğelerine sosyolojik psikolojik, tarihsel ve mistik anlamlar yüklenmiştir (örneğin Eden Bahçeleri, Kırklar Dağı gibi). 
Bugünün çevre sistemlerini (nehir, toprak, yeraltı suyu, tektonizma) anlamak için geçmişin çevresel dinamiklerini anlamak, bunun yanında insanlık tarihi diliminde ve geçmiş uygarlıklar döneminde çevrenin nasıl algılandığını, nasıl kullanıldığını çevre ile insan arasında nasıl bir organik bağ olduğunu belirlemek zorundayı. Bu bağlamda Dicle Nehri vadisinde bir sonraki aşamada yapılması gereken çalışmalar :

- Volkanik ve diğer karasal çökeller altındaki geçmişe ait eski rölyef bağlantılarının kurulmas1,

- Çökel bulgularının yaşlandırılması ile Kuvaterner kronolojisinin kurulması ve incelenmesi,

- Paleocoğrafya ve iklim değişimlerinin nehir peyzajına etkilerinin incelenmesi olarak belirlenmiştir.

Sonuç olarak Diyarbakır civarında geçmişte kültür, insan ve nehir peyzajı etkileşiminin açıklanmasıyla kültürel jeoloji-jeomorfoloji adına önemli bir kapı aralanmış olacaktır.

\section{EXTENDED SUMMARY}

Environment and environmental systems have memories which become heritages common to several civilizations. The river and valley systems at Diyarbakır are such a heritage, which is now part of the UNESCO List of Natural and Cultural World Heritage. The future of this heritage depends on the choices and actions of human beings and on the other hand the influence of the developmental process and the dynamics of the stream system. This history is recorded in the terraces stretching along the river flood plain, and in the relationships between the river and the substratum that it incises.
Below the citadel city of Diyarbakur (the Hevsel Gardens), thick fluvial deposits recording a long usage by successive civilizations. In this context, we initiated a research program on the geomorphology of the Tigris terraces, starting below the citadel (right bank), at the foot the University grounds (left bank), and southward beyond the gorges enclosing the Hevsel Gardens.

Due to geomorphological questionings rising southwards, we also directed our research toward the Karacadağ basaltic flows bordering the Tigris valley to the west. In spring and autumn 2014, we performed a systematic field study in the Hevsel Gardens. GPS measurements allowed us to draw a transverse profile of embedded terraces, which records the progressive sliding and widening of a Tigris meander towards the SE. We also performed a preliminary hand-coring in the fill of an abandoned channel. Transferring the profiles to satellite imagery and old photographs, we draw a map of the records of changes in the riverbed downslope the city wall.

In spring 2015, aiming at dating various phases in the alluvial deposition and erosion activity of the river during the Holocene, we performed two truck-mounted corings in the left bank terraces north of the city.

Our first results provide new insights into the recent evolution of the Tigris valley and River.

According to these results;

- $\quad$ it appears that the terraces represent as much climate changes as tectonic triggering the meander sliding southeastwards.

- $\quad$ The scarp below the city walls of Diyarbakir, may partly or totally result from a rupture triggering the downsliding of pieces of the upper basalt flow. 
- $\quad$ The fault scarp (spotted line red) has been partly revealed by the river erosion before the deposition of the oldest terrace.

- Incision of the bedrock (the Neogene Selmo formation) by the river points to possible impact of uplift in the area, or to a possible lowering of the base-level (subsidence? erosion?) downstream.

- From Late Glacial to Early Holocene the riverbed changed location because of regular and abundant discharges. The $+8 /+9 m$ older terrace was only reached by high floods depositing (organic) clay sediments intermingled with some more gravely sediments indicating that floods could reach great height.

- While, since the Mio-Pliocene, the volcanic activity of the Karadag massif modified at times the morphological context of the area, tectonic uplift and possibly associated faulting rejuvenated and still command partly (with climate) the river and slope dynamics (polycyclic geomorphological evolution).

- Reconstructing past morphological connections (e.g. surfaces, erosion systems) in relation to fossil topographies and correlative deposits connected to dated volcanic products and morphologies;

- Establishing a chronology of this evolution based on 14C or OSL ages of sediments, $K-A r$ or Ar-Ar dating of volcanics

- Identifying palaeoclimatic changes possibly recorded in sediment dynamics and in the morphological evolution of the valley system

Two important scientific impacts are expected from this project's results:
(1) a contribution to the investigation of the interactions between human cultures and societies with the river in the past;

(2) a highlight on the roles, in today's and future dynamics, of the processes recorded in the archives we study.

Such ultimate results of our research will directly address the management and preservation of the Hevsel Gardens and Tigris River valley in the Diyarbakir area.

\section{DEĞIINILEN BELGELER}

Altunel, E. 2012. Kültürel Jeoloji: Jeoloji’nin İnsanoğlunun Yaşamı Üzerindeki Etkileri. İç: Kuvaterner Bilimi (Ed.: Kazanc1, N. ve Gürbüz, A.), Ankara: Ankara Üniversitesi Yayınları No: 350, s.: 195-214.

Bridgland D.R., Demir T., Seyrek A., Pringle M., Westaway R., Bieck A.R., et al., 2007. Dating quaternary volcanism and incision by the river Tigris at Diyarbakir, southeast Turkey. Journal Of Quaternary Science, vol.22, pp.387-393.

Doğan, U., 2005a. Land subsidence and caprock dolines caused by subsurface gypsum dissolution and the effect of subsidence on the fluvial system in the Upper Tigris Basin (Between Bismil-Batman, Turkey). Geomorphology 71, 389-401.

Doğan, U., 2005b. Holocene fluvial development of the Upper Tigris Valley (Southeastern Turkey) as documented by archaeological data. Quaternary International. c. 129. s. 1: 75-86.

Karadoğan, S., 2015. Yerleşmeye Etkileri Açısından Diyarbakır Kenti ve Yakın Çevresinin Doğal Peyzaj Unsurları. Diyarbakır Büyükşehir Belediyesi, Diyarbakır Kalesi ve Hevsel Bahçeleri Kültürel Peyzaj1, Alan Yönetimi Başkanlığı Yayınları: 4, s:1-17,(Türkçe Kitap Bölümü) 
Karadoğan, S., Kozbe, G., 2013. Yukarı Dicle Havzasının (Batman-Bismil Arası) Jeomorfolojik Özellikleri ve Arkeolojik Yerleşme/Buluntu Yerlerinin Dönemler Boyunca Mekan Etkileşimleri. Geomorphology of Holocene records in Turkey (İlhan Kayan için Armağan Yazılar). ed. Ertuğ Öner, Izmir Univ. Pub., Izmir. c. $181: 540-564$.

Kazanc1, N., 2005. Kültürel Jeoloji. Mavi Gezegen 12, 4-5.

Kuzucuoğlu, C., 2002. Preliminary observation on the Tigris Valley terraces between Bismil and Batman. Salvage Project of the Archaeological Heritage of the Ilısu-Carchemish Dam Reservoirs Activities in 2000. ed. Numan Tuna, Jale Velibeyoğlu, METU, Ankara: 759-771.

Perez, A., 2015. Hevsel Bahçeleri ve Cennet Bahçesi Efsanesi, Diyarbakır Kalesi ve Hevsel Bahçeleri Kültürel Peyzajı. ed. N. Soyukaya, Diyarbakır:
Diyarbakır Kalesi ve Hevsel Bahçeleri Alan Yönetimi, 131-142

Westaway R., Guillou H., Seyrek A., Demir T., Bridgland D., Scaillet S., et al., 2009. Late Cenozoic surface uplift, basaltic volcanism, and incision by the River Tigris around Diyarbakir, SE Turkey, International Journal Of Earth Sciences, vol.98, pp.601-625.

$\begin{array}{ll}\text { Makale Geliş Tarihi } & : 1 \text { Temmuz } 2016 \\ \text { Kabul Tarihi } & : \text { 18 Aralık } 2016 \\ \text { Received } & : \text { 1 July 2016 } \\ \text { Accepted } & : \text { 18 December } 2016\end{array}$

